\title{
Persepsi Orang Tua Terhadap Sistem Pembelajaran Online Siswa SD Di Masa Pandemi COVID-19 (Analisis Validitas Dan Reliabilitas Instrumen)
}

\author{
Rochyani Lestiyanawati ${ }^{1}$,Nugroho Prasetya $\mathrm{Adi}^{* 2}$,
}

${ }^{1}$ Pendidikan Bahasa Inggris, Fakultas Bahasa dan Sastra, Universitas Sains Al-Qur'an, Indonesia

${ }^{2}$ Pendidikan Fisika, Fakultas Ilmu Tarbiyah dan Keguruan, Universitas Sains Al-Qur'an, Indonesia

Email: 1yannealsyannie@gmail.com, ${ }^{2}$ nugrohoprasetyaadi@gmail.com

\begin{abstract}
Abstrak
Penyebaran virus covid-19 di Indonesia memberikan dampak yang signifikan, salah satunya adalah pada bidang pendidikan. Dimana gelombang pembelajaran daring/ online sangat masif penyebaran nya. Perubahan proses pembelajaran dari tatap muka langsung menjadi daring/ online merupakan salah satu cara yang dilakukan Pemerintah melalui Kementerian Pendidikan dan Kebudayaan untuk memutus penyebaran virus covid-19. Namun, belum siapnya sumber daya manusia untuk melaksanakan pembelajaran daring/ online di era pandemi memunculkan problematika baru. Salah satunya adalah faktor orang tua siswa, dimana kebanyakan orang tua siswa belum siap dan belum mampu sepenuhnya menggantikan peran guru pada proses pembelajaran online. Penelitian ini merupakan penelitian kualitatif dengan metode survei yang dilakukan secara online. Tujuan dari penelitian ini adalah untuk mengetahui validitas dan reliabilitas instrument persepsi orang tua siswa, serta untuk mengetahui persepsi orang tua terhadap pembelajaran daring/ online di era pandemi. Teknik pengumpulan data pada penelitian ini adalah menggunakan angket yang telah divalidasi, baik validasi isi, keterbacaan, maupun validasi empiris. Hasil penelitian menunjukkan bahwa instrumen angket persepsi orang tua bernilai valid dan reliabel berdasarkan validasi isi oleh ahli, serta bernilai valid dan reliabel berdasarkan validasi empiris dengan bantuan program Quest.
\end{abstract}

Kata kunci: Persepsi Orang Tua, Pembelajaran Online, Pandemi Covid-19

\section{Parents Perception of the Online Learning System on Elementary School Students During the COVID-19 Pandemic}

\begin{abstract}
The spread of the Covid-19 virus in Indonesia has had a significant impact, one of which is in the field of education. Where the wave of online learning is very massive in its spread. The change in the learning process from face-to-face to online system is one of the ways the Government through the Ministry of Education and Culture to stop the spread of the covid-19 virus. However, the unpreparedness of human resources to carry out online learning in the pandemic era raises new problems. One of them is the parent factor, where most parents are not ready and haven't been able to fully replace the teacher's role in the online learning process. This research is a qualitative research with a survey method conducted online. The aim of this study was to determine the validity and reliability of the instrument and to determine the parents perception of online learning in the pandemic era. The data collectiob technique in this study was using a validated questionnaire, both content validation, legibility, and empirical validity. The result showed that the parents perception questionnaire instrument was valid and reliabel based on content validation by experts, and valid and reliabel based on empirical validation with the help or the Quest program.
\end{abstract}

Keywords: Parents Perception, Online Learning, Covid-19 Pandemic

\section{PENDAHULUAN}

Masuknya virus covid-19 ke Indonesia pada bulan maret 2020 memberikan dampak yang signifikan terhadap beberapa sektor kehidupan. Sektor-sektor yang terkena dampak dari penyebaran virus covid-19 adalah ekonomi, pangan, pariwisata, transportasi, kesehatan, sosial, serta pendidikan [1]. Pendidikan merupakan salah satu sektor yang terkena dampak dari penyebaran virus korona di Indonesia. Dampak positif yang diterima pada bidang pendidikan antara lain adalah meningkatkan kompetensi pendidik, kolaborasi orang tua dan pendidik yang semakin erat, serta penerapan gaya belajar abad 21 [2]. Selain dampak positif, adapun dampak negatif yang ditimbulkan dari penyebaran virus korona pada bidang pendidikan, yaitu sarana prasarana yang belum sepenuhnya terpenuhi serta SDM yang belum siap dalam menjalankan pembelajaran secara daring/online [3]. 
Kebijakan pembelajaran secara daring/ online dipilih guna mengurangi dampak penyebaran virus covid-19 di Indonesia. Surat edaran no 4 tahun 2020 tentang pelaksanaan kebijakan pendidikan dalam masa darurat penyebaran coronavirus disease (covid-19) yang dikeluarkan oleh Kementerian Pendidikan dan Kebudayaan Indonesia menyebutkan bahwa kesehatan serta keselamatan peserta didik, pendidik, tenaga kependidikan, keluarga, dan masyarakat merupakan prioritas utama dalam menetapkan kebijakan pembelajaran daring [4]. Tidak hanya di Indonesia, tsunami pembelajaran daring juga telah merambah hampir ke seluruh dunia selama pandemic covid-19 [5].

Guru dan orang tua sebagai elemen penting dalam proses pembelajaran daring diharuskan melakukan migrasi besar-besaran yang belum pernah terjadi sebelumnya dimana peran orang tua menjadi lebih vital dalam proses pembelajaran dibandingkan peran guru di era pandemic [6]. Perubahan peran orang tua dalam proses pembelajaran daring menuntut orang tua untuk mampu mengasuh dan mendidik anak-anak nya untuk menguasai materi pembelajaran yang diberikan oleh guru. Sebagai pengganti guru dalam proses pembelajaran daring sejatinya orang tua memiliki peran yang sangat vital. Terdapat 4 peran orang tua selama proses pembelajaran daring berlangsung, yaitu 1) Orang tua memiliki peran sebagai guru di rumah, yang dimana orang tua dapat membimbing anaknya dalam belajar secara jarak jauh dari rumah, 2) orang tua sebagai fasilitator, yaitu orang tua sebagai sarana dan prasarana bagi anak dalam melaksanakan pembelajaran daring, 3) orang tua sebagai motivator, yaitu orang tua dapat memberikan semangat serta dukungan kepada anaknya dalam proses pembelajaran, 4) orang tua sebagai pengaruh [7].

Namun dalam praktiknya, banyak orang tua yang mengeluh dengan berubahnya peran orang tua menjadi seorang pendidik bagi anak-anaknya di era pandemi covid-19. Belum siapnya orang tua, serta tidak mampu nya orang tua dalam membantu proses belajar anak menjadi kendala bagi sebagian orang tua siswa [8]. Selain itu banyak nya tugas yang harus diselesaikan oleh siswa dalam jangka waktu tertentu membuat banyak orang tua siswa semakin mengeluh dengan keadaan pendidikan di era pandemic [9].

\section{METODE PENELITIAN}

Penelitian ini merupakan penelitian kualitatif deskriptif. Penelitian kualitatif merupakan metode penelitian yang digunakan untuk meneliti pada kondisi objek yang alamiah dimana peneliti sebagai instrument kunci [10]. Metode penelitian yang digunakan adalah survei yang dilakukan secara online. Jenis penelitian ini mengarah pada kajian fenomenologis yang memiliki perhatian khusus terhadap fenomena yang diteliti serta focus terhadap subjek penelitian. Subjek dari penelitian ini adalah orang tua siswa yang menempuh pendidikan di tingkat sekolah dasar di Kabupaten Wonosobo. Pengumpulan data dilakukan menggunakan angket online. Sebelum digunakan untuk proses penelitian, angket dilakukan validasi terlebih dahulu untuk mengetahui validitas dan reliabilitas dari angket tersebut. Validitas instrument dicari menggunakan bantuan software quest dengan teori respon butir/ IRT [15] [16]. Subjek yang digunakan untuk menghitung validitas instrument sebanyak 60 orang, jumlah ini dipilih berdasarkan ukuran sampel terkecil yang bisa digunakan untuk mengukur validitas dan reliabilitas instrument yaitu 30 [17] [18]. Sehingga data yang dihasilkan akan sesuai dengan tujuan penelitian yang ditetapkan.

\section{HASIL DAN PEMBAHASAN}

Validasi instrument dilakukan untuk mengetahui apakah instrument yang digunakan sudah valid dan reliabel. Instrument yang dikembangkan berdasarkan pada aspek dan indikator berkaitan dengan pembelajaran daring di era pandemic. Tujuan dilakukannya validasi instrument adalah agar instrument yang dikembangkan dapat digunakan untuk mengukur apa yang seharusnya diukur. Validasi instrument dilakukan dalam tiga tahap, yaitu validasi isi, validasi keterbacaan, serta validasi empiris.

Tahap pertama yaitu validasi isi, validasi isi dilakukan oleh 5 orang ahli untuk mengetahui kevalidan isi dari instrument tersebut. Validitas isi ditentukan dengan menggunakan kesepakatan ahli. Kesepatakan ahli diukur dengan menentukan tingkat validitas isi instrument. Validasi isi dibuktikan dengan menggunakan CVR dan CVI atau koefisien Aiken. CVR dan CVI diusulkan pertama kali oleh Lawshe pada tahun 1975, dengan menggunakan tiga rating penilaian [11]. Tahun 1985, Aiken mengusulkan konsep validitas isi dengan lebih rinci. Kerincian terlihat dari standar kevalidan yang dipengaruhi oleh jumlah rater/ penilai dan skala rating yang digunakan [12]. Penggunaan cara pembuktian harus memperhitungkan asumsi atau syarat yang harus dipenuhi, sedangkan untuk pembuktian validitas dengan menggunakan konsep dari Lawshe (1975) yang menggunakan tiga skala rating, yaitu 1) esensial, 2) berguna namun tidak esensial, dan 3) tidak perlu. Validasi isi oleh Lawshe dapat ditentukan dengan persamaan [13].

$$
\mathrm{CVR}=\frac{2 n e}{n}-1
$$


Hasil validasi instrumen isi oleh ahli disajikan pada Tabel 1 berikut

Tabel 1. Hasil Validasi Isi oleh Ahli

\begin{tabular}{cccc}
\hline Instrumen & Validity Coeficient $(V)$ & Intepretasi & Reliabilitas \\
\hline Angket Persepsi Orang Tua & 1,00 & Valid & Reliabel \\
\hline
\end{tabular}

Berdasarkan pada Tabel 1, dapat dilihat bahwa instrument yang digunakan telah memenuhi kriteria valid dan reliabel berdasarkan penilaian ahli pada proses validasi isi. Dimana validity coefficient (V) Aiken di dapatkan nilai 1,00, yang artinya mempunyai nilai kevalidan. Seperti dijelaskan oleh Lawshe pada Tabel 2 berikut [14]

Tabel 2. Standar Minimum CVR berdasarkan SME (Subject Matter Expert)

\begin{tabular}{cc}
\hline Jumlah $S M E$ & Nilai Minimum $C V R$ \\
\hline 5 & 0,99 \\
6 & 0,99 \\
7 & 0,99 \\
8 & 0,75 \\
9 & 0,78 \\
10 & 0,62 \\
\hline
\end{tabular}

Validasi empiris dilakukan untuk mengetahui validitas dan reliabilitas instrument setelah instrument digunakan oleh subjek ujicoba. Validitas empiris diperoleh dari analisis respon terhadap instrument yang diberikan kepada subjek ujicoba. Validitas empiris dapat diuji menggunakan Classical Test Theory (CTI) atau Item Response Theory (IRT) [15] [16]. Validasi empiris dilakukan pada 60 orang subjek coba. Penentuan subjek coba sebanyak 60 orang berdasarkan pada minimum subjek yang dapat digunakan untuk mengetahui validitas dan reliabilitas untuk validasi empiris. Ukuran sampel terkecil yang baik untuk memperkirakan kevalidan produk yang dikembangkan adalah 30 [17] [18]. Data yang diperoleh dari validitas empiris diuji IRT menggunakan bantuan program Quest.

Adapun hasil validasi empiris disajikan pada Tabel 3 Berikut

Tabel 3. Hasil Validitas Empiris

\begin{tabular}{cccccc}
\hline No Butir & $\begin{array}{c}\text { Infit } \\
\text { MNSQ }\end{array}$ & Intepretasi & Outfit MNSQ & Intepretasi & Reliabel of Estimate \\
\hline 1 & 0,97 & Cocok & 0,88 & Lolos & \\
2 & 0,97 & Cocok & 0,86 & Lolos & \\
3 & 1,19 & Cocok & 1,17 & Lolos & \\
4 & 0,98 & Cocok & 0,92 & Lolos & \\
5 & 1,14 & Cocok & 1,21 & Lolos & \\
6 & 0,89 & Cocok & 0,86 & Lolos & \\
7 & 1,08 & Cocok & 1,08 & Lolos & \\
8 & 0,91 & Cocok & 0,91 & Lolos & \\
9 & 1,10 & Cocok & 1,11 & Lolos & \\
10 & 1,08 & Cocok & 0,98 & Lolos & \\
11 & 0,88 & Cocok & 0,85 & Lolos & \\
12 & 1,00 & Cocok & 0,95 & Lolos & \\
13 & 1,00 & Cocok & 0,92 & Lolos & \\
14 & 0,91 & Cocok & 0,91 & Lolos & \\
15 & 0,91 & Cocok & 0,80 & Lolos & \\
\hline
\end{tabular}

Item Fit

all on all $(\mathrm{N}=59 \mathrm{~L}=15$ Probability Level $=.50)$ 


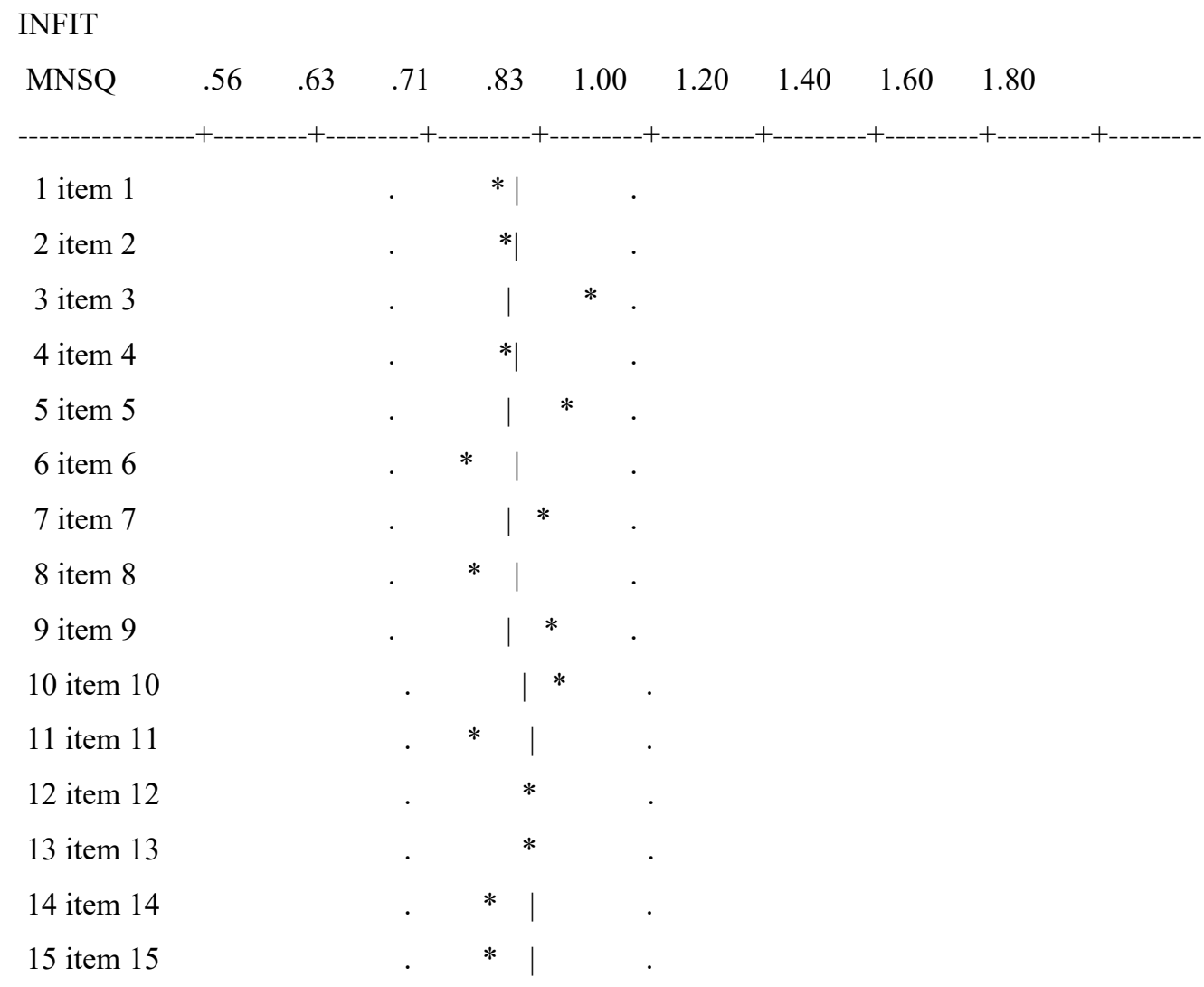

Berdasarkan pada Tabel 3 dan hasil analisis validitas empiris menggunakan program Quest, didapatkan bahwa butir pernyataan dalam angket persepsi orang tua valid dan reliabel. Butir pernyataan dinyatakan valid apabila nilai INFITMNSQ berada pada rentang 0,77 - 1,30 [19]. Sehingga butir-butir pernyataan dalam angket dapat digunakan untuk diujicobakan pada skala luas.

\section{KESIMPULAN}

Penelitian yang dilakukan untuk mengetahui validitas dan reabilitas instrument persepsi orang tua dalam pembelajaran daring. Validitas instrument dilakukan dalam tiga tahap, pertama validitas isi yang dilakukan oleh 5 orang ahli dengan hasil instrument valid dan reliabel berdasarkan perhitunan CVR dan Aiken. Kedua validitas empiris yang dilakukan pada 60 orang subjek coba untuk mengetahui validitas dan reliabilitas butir angket. Uji validitas empiris dilakukan dengan bantuan program Quest, dimana hasil dari validitas nya adalah semua butir pernyataan dalam angket dinyatakan valid dan reliabel, sehingga dapat digunakan untuk penelitian dalam skala luas.

\section{DAFTAR PUSTAKA}

[1] Handarini, O. I. \& Wulandari, S. S. "Pembelajaran Daring Sebagai Upaya Study from Home (SFH) Selama Pandemi Covid-19”. Jurnal Pendidikan Administrasi Perkantoran (JPAP). 2020. Vol 8, No 3. Pp 496-503

[2] Cahyati, N. \& Kusumah, R. Peran Orang Tua dalam Menerapkan Pembelajaran di Rumah Saat Pandemi Covid-19. Jurnal Golden Age. 2020. Vol 4, No. 1. Pp.152-159.

[3] Anugrahana, A. "Hambatan, Solusi, dan Harapan: Pembelajaran Daring Selama Masa Pandemi Covid-19 oleh Guru Sekolah Dasar”. Scholaria: Jurnal Pendidikan dan Kebudayaan. 2020. Vol 10, No. 3. Pp 282289.

[4] Khasanah, et al. "Pendidikan dalam Masa Pandemi Covid-19". Jurnal Sinestesia. 2020. Vol 10, No 1. pp 41-48.

[5] Goldschmidt, K. \& Msn, P. D. "The Covid-19 pandemic. Technology use to support the wellbeing of children". Journal of Pediatric Nursing. 2020. Xxx, 3-5. https://doi.org/10.1016/j.pedn.2020.04.013. 
[6] Herliandry, et al. "Pembelajaran pada Masa Pandemi Covid-19”. Jurnal Teknologi Pendidikan. 2020. Vol 22 No 1. pp 65-70.

[7] Winingsih, E. "Peran Orang Tua Dalam Pembelajaran Jarak Jauh. April 2, 2020". 2020. Poskita.co: https://poskita.co/2020/04/02/peran-orangtua-dalampembelajaran-jarak-jauh/ (Accessed, Juni 2021)

[8] Lailiyatul, S., \& Mariyana, F. "Peran Orang Tua dalam Mendampingi Anak di Rumah Selama Pandemi Covid-19". Journal of Chilhood Education. 2020. Vol 4, No 2. Pp. 71-81.

[9] Roshonah, A. F. et al. "Peran Orang Tua dalam Membimbing Anak Selama Pembelajaran Daring di Rumah". Seminar Nasional Pengabdian Masyarakat LPPM UMJ. 2020. pp 1-8

[10] Sugiyono. "Metode Penelitian Pendidikan: Pendekatan Kuantitatif, Kualitatif, dan R\&D”. 2012. Bandung: Alfabeta

[11] Bashooir, K., \& Supahar. "Validitas dan Reabilitas Asesmen Kinerja Literasi Sains Pelajaran Fisika Berbasis STEM”. Jurnal Penelitian dan Evaluasi Pendidikan. 2018. Vol 22, No 2. Pp. 219-230.

[12] Aiken, L. R. "Three Coefficient for Analyzing the Reability and Validity of Rating”. Jurnal Educational and Psycological Measurement. 1985. Vol 45, No1. pp 131-142.

[13] Azwar, S. "Reabilitas dan Validitas (4 ${ }^{\text {th }}$ ed)". 2012. Yogyakarta: Pustaka Belajar.

[14] Lawshe, C. H. "A Quantitative Approach to Content Validity". Jurnal Personnel Psycology. 1975. Vol 28, No 4. pp 563-575.

[15] Sumintono, B., \& Widhiarso, W. “Aplikasi Pemodelan RASCH pada Assesment Pendidikan”. 2015. Cimahi: Tim Komunikata Publishing House.

[16] Retnawati, H. "Validitas Reliabilitas dan Karakteristik Butir". 2016. Yogyakarta: Parama Publishing.

[17] Adi, N. P. \& Faisal, V. I. A. "Development of PIAUD Science Learning Media (PSLM) Based on Wonosobo Local Wisdom”. 2021. In Proceeding of the $6^{\text {th }}$ International Seminar on Science Education, Atlantis Press, pp. 648-654.

[18] Adi, N. P. \& Faisal, V. I. A. “Analisis Kelayakan Materi PIAUD Science Learning Media (PSLM) Berbasis Wonosobo Local Wisdom”. Jurnal Golden Age. 2020. Vol 4, No.1. pp 59-68.

[19] Subali, B. \& Suyata, P. "Pengembangan Instrumen Tes Konvergen dan Divergen: Penyelidikan Validitasnya Secara Empiris”. 2012. Yogyakarta: Diandra Pustaka Indonesia. 